\title{
Awareness of mobile phone hazards among university students in a malaysian medical school
}

\author{
Latha Rajendra Kumar*, Kiu Dawn Chii, Lye Chuan Way, Yogeeta Jetly, Veena Rajendaran
}

Faculty of Medicine, Asian Institute of Medical Science and Technology, Bukit Air Nasi, Kedah, Malaysia;

*Corresponding Author: latha.rajendrakumar@gmail.com

Received 6 January 2011; revised 28 January 2011; accepted 30 February 2011.

\begin{abstract}
This paper seeks to examine the awareness of potential health hazards by using mobile phone among AIMST (Asian Institute of Medical science and technology) University students. This is a cross-sectional survey conducted by distributing 'perception questionnaire'. Perception of health hazards and outcomes were compared by gender, age, course of study, preferred ear, number of calls and SMS daily, the brand of mobile phone and use of mobile phone accessory (Bluetooth and hands free). The overall perception of mobile phone hazard in AIMST university student was 62\%.Most subjects agreed that mobile phone usage can cause headache, loss of mental attention and sleeping disturbances and most disagree that mobile phone usage can cause constipation and diarrhea. Out of the 124 subjects who were aware of the side effects, $5 \%$ of the males and $10 \%$ of the females felt that there was no need to minimize the unwanted effects. The paper is useful to the general population particularly to the students as the perceived health risk did not significantly deter students from using mobile phone. The reasons given by students for the continued usage of mobile phone in spite of their awareness of the associated hazards have been discussed. This study offers new insight into level of awareness and perception of mobile phone hazard among University students.
\end{abstract}

Keywords: Mobile Phone; Hazards; Perception Questionnaire; University Students

\section{INTRODUCTION}

A mobile phone is a long-range, electronic device used for mobile voice or data communication over a network of specialized base stations known as cell sites. In addi- tion to the standard voice function of a mobile phone, current mobile phones may support many additional services, and accessories, such as SMS for text messag- ing, email, packet switching for access to the Internet, gaming, Bluetooth, infrared, camera with video recorder and MMS for sending and receiving photos and video, MP3 player, radio and GPS. Most current mobile phones connect to a cellular network of base stations (cell sites), which is in turn interconnected to the public switched telephone network (PSTN) (the exception is satellite phones).

The dependence on the mobile phone is increasingly high.At the same time, this new information and communication technology may cause harm. Although there are only a few studies of mobile phone use, it has been suggested that excessive mobile phone use may be associated with health-compromising behaviors, such as smoking or alcohol drinking [1]. Some previous studies of Internet use suggest that excessive Internet use may be associated with subjective distress, loneliness and social isolation [2]. There is concern that microwaves might induce or promote cancer, and the symptoms associated with their use include sleep disturbance, memory problems, headaches, nausea, and dizziness [3]. Changes in the permeability of the blood-brain barrier, electroencephalographic activity, and blood pressure have also been reported [4].

However, health concerns have induced a large body of research (both epidemiological and experimental, in non-human animals and in humans). Tantalizing findings in humans include a speeding up of reaction time during exposure, particularly during behavioral tasks calling for attention, and electroencephalographic changes during cognitive processes [5-9]. The only established health hazard cited by the independent group comes from the use of mobile phones while driving. The risk is the same when the phone is used "hands free" (via a loudspeaker or a hands free device), implying that it is due to the distraction caused by the conversation.

A study carried out by the Center for Reproductive 
Medicine, Cleveland Clinic, USA [10] have published a comprehensive, up-to-the-minute overview of the effects of cell phone exposure on human health.In another such research, by Siegrist $\mathrm{M}$ et al. [11] , studied the perceptions of risks associated with mobile phones, base stations, and other sources of electromagnetic fields (EMF). Results showed people who use their mobile phones frequently perceived lower risks and higher benefits than people who use their mobile phones infrequently. Study conducted by Hutter et al., [12,13] on adverse health effects of mobile phones and their base stations.

Objectives

1) To find out the percentage of students in AIMST University who have awareness of the hazards of mobile phone.

2) To find out which of the hazards of mobile phone use has greater perception among AIMST Students.

3) To find out how many students actually practice any safety measures to minimize the unwanted ef- fects of mobile phone.

4) To look for ways and means the student population is trying to minimize the unwanted effects.

We hypothesized that less than $50 \%$ of the AIMST student population would have perception of the hazards of mobile phone usage.

Methods: During our survey, 233 questionnaires were randomly given around the campus. However not all the student responded to the survey? Of the 233 questionnaire given, 212 were respondents however some questionnaire was incompletely filled and their data could not be included in study.

Questionnaire was prepared and pilot tested on 10 students and peers reviewed by senior staff. The ethical clearance committee clearance was thus obtained. (Appendix 1)

Informed Consent was obtained [14-16] from the participants.

\section{DATA ENTRY INTO EPI INFO (FIGURE 1)}

1) Question 3: Gender : M-male, F-female

2) Question 8: Do you use a cell phone : Y-yes, N-no

3) Question 12: 1-pouch, 2-hip-pocket, 3-around your neck, 4-in the bag, 5-any other

4) Question 15: 1-right, 2-left, 3-both, 4-not sure

5) Question 17 and 18: Y-yes, N- no

6) Question I:1-strongly disagree, 2-disagree, 3-slightly agree, 4-agree, 5-strongly agree

Question III: Y-yes, N-no

A survey was randomly done on 200 students of AIMST UNIVERSITY. The 200 students, who responded to our survey, comprised of 79 (39.5\%) males and 121 (60.5\%) females. (Figure 2)
The distribution of the sample population in AIMST University. BDS (dentistry), BIT (Information technology), BM (business management), Bpharm (pharmacy), BTC (biotech), FIS (foundation in science), MBBS (medicine), PT (physiotherapy). (Figure 3)

\section{RESULTS AND DISCUSSION}

One of the subject was using the mobile phone for 15 years. Most subjects have been using their mobile phone for 5 years. (Figure 4)

$78 \%$ males and $84 \%$ females have at least one mobile phone. (Table 1)

5 most popular brands were chosen. The most favourite mobile phone brand used is Nokia (53.5\%), followed by Sony Ericsson (34\%). Multitech, O2 and HTC are very uncommon (Figure 5).

Among the males, $49.45 \%$ used Nokia, and $34.07 \%$ used Sony Ericsson.

Among the females $48.82 \%$ used Nokia, and 29.13\% used Sony Ericsson (Figure 6).

Gender vs Brand.

4 most common locations for placements of mobile phone were chosen in the research and placement of mobile in the pocket was the most popular choice. However, none of our subjects put their phone around their neck (Figure 7).

Out of the 200 samples, 199 responded to the question “average calls per day including incoming and outgoing”. Most of subject made 5 calls perday (20.1\%) and 2 calls perday (19.5\%). The total average of incoming and outgoing calls is 4.93 calls per day per person (Table 2, Figure 8).

Most of the subjects have their mobile phone usage at average 5 minutes per day (16.5\%) and 30 minutes per day $(11.5 \%)$. The highest average call duration is 360 minutes per day and the lowest average call duration is 1 minutes per day. The total average call duration of the 200 subject is 32.245 minutes per day per person (Figure 9).

From the graph, there is not much significant difference of the perception between males and females on the same category $(<10 \%)$.Most subjects agreed that mobile phone usage can cause headache, loss of mental attention and sleeping disturbances and most disagree that mobile phone usage can cause constipation and diarrhea (Figures 10-13).

Out of the 200 subjects under the survey, 124 subjects were aware of the side effects of mobile phone usage. (78 females and 46 males were aware of the hazards) (Figures 14 and 15).

Out of the 124 subjects who were aware of the side effects, $5 \%$ of the males and $10 \%$ of the females felt that there is no need to minimize the unwanted effects (Figure 16). 


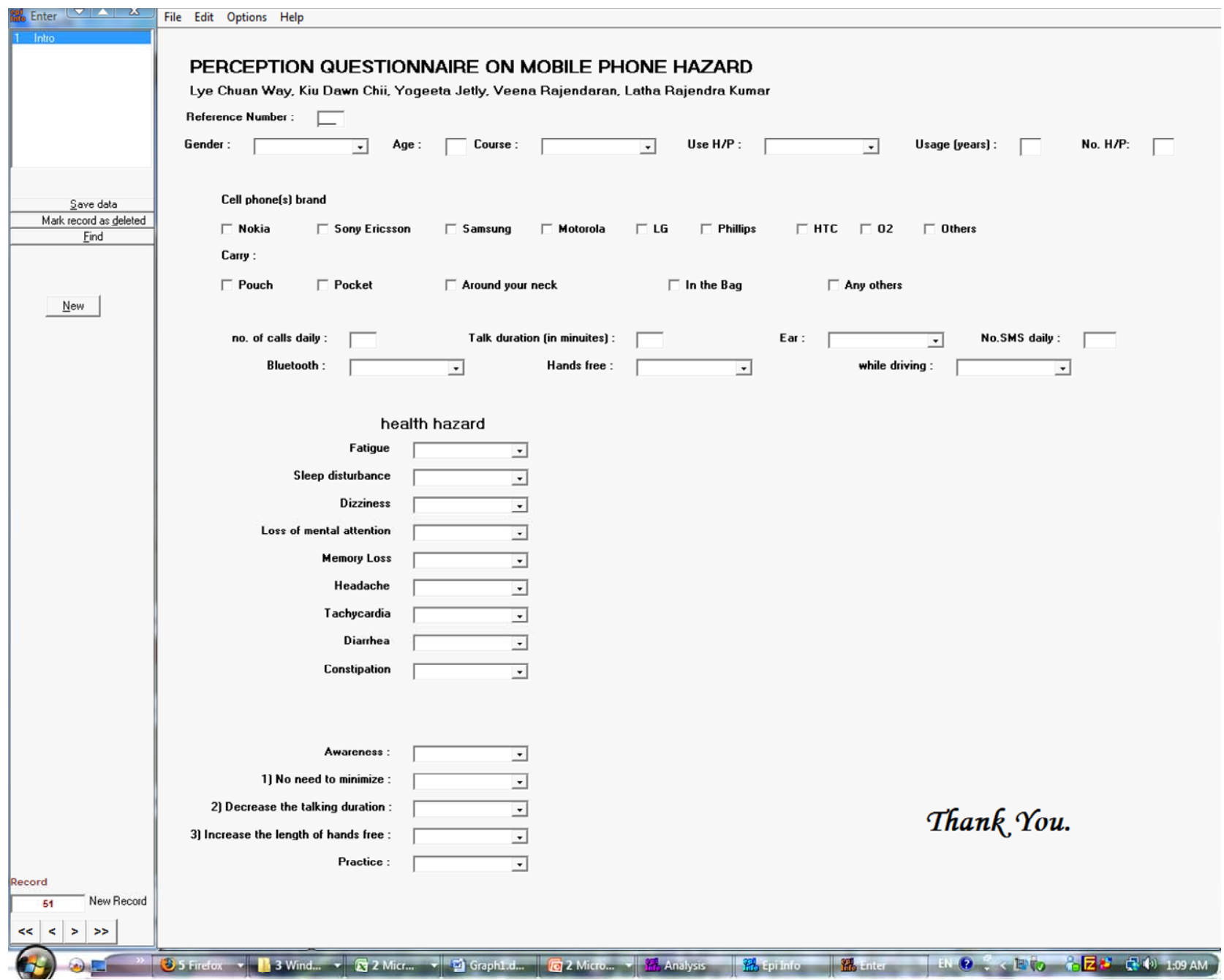

Figure 1. Individual data was entered into this page, on Epi Info 2007.The following coding was done for data entry.

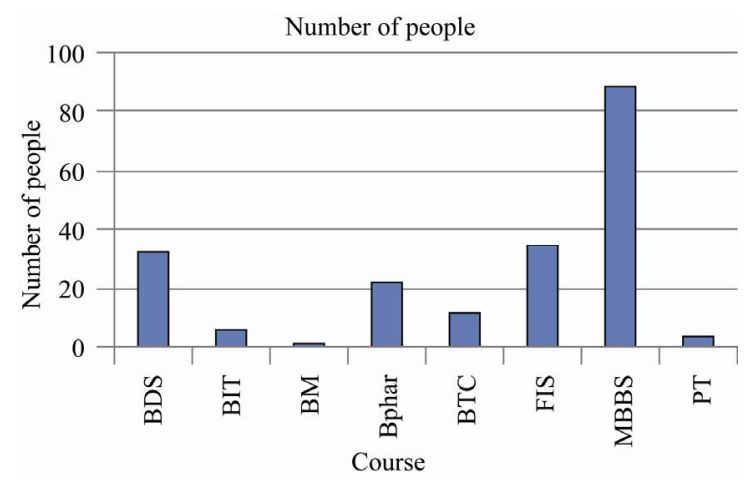

Figure 2.

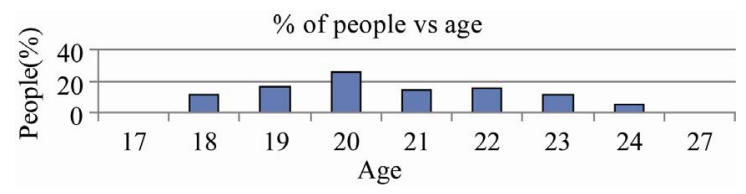

Figure 3. Distribution of subjects according to age.
$\%$ of people vs duration of mobile phone usage (in years).

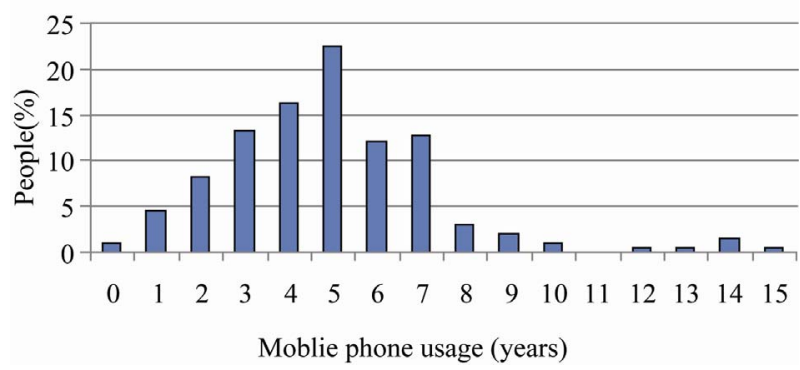

Figure 4. Distribution vs years of mobile phone usage.

Significant perception of mobile phone hazard was observed in the age group of 22 years.

Our study disclosed $62 \%$ of the student population are aware of the EMF health hazards produced by mobile phone usage. Martha and Griffet [17] have reported that adolescents appear to be concerned with perception of 
Table 1. Distribution of number of students according to the number of mobile phone they use.

\begin{tabular}{|c|c|c|c|c|c|c|c|c|}
\hline $\begin{array}{c}\text { number of } \\
\text { mobile phone }\end{array}$ & $\begin{array}{c}\text { Number of } \\
\text { subjects }\end{array}$ & $\begin{array}{c}\% \text { of } \\
\text { subjects }\end{array}$ & $\begin{array}{c}\text { Number of } \\
\text { Male }\end{array}$ & $\begin{array}{l}\text { Number of } \\
\text { Female }\end{array}$ & $\%$ of Male & $\%$ of Female & $\begin{array}{c}\% \text { of all } \\
\text { Male }\end{array}$ & $\begin{array}{l}\% \text { of all } \\
\text { Female }\end{array}$ \\
\hline 1 & 163 & 81.91 & 62 & 101 & 38.04 & 61.96 & 78.481 & 84.167 \\
\hline 2 & 24 & 12.06 & 10 & 14 & 41.67 & 58.33 & 12.658 & 11.667 \\
\hline 3 & 6 & 3.015 & 3 & 3 & 50 & 50 & 3.797 & 2.5 \\
\hline 4 & 4 & 2.01 & 3 & 1 & 75 & 25 & 3.797 & 0.833 \\
\hline 5 & 1 & 0.503 & 0 & 1 & 0 & 100 & 0 & 0.833 \\
\hline 6 & 1 & 0.503 & 1 & 0 & 100 & 0 & 1.266 & 0 \\
\hline
\end{tabular}

Table 2. Average calls made per day by the subjects.

\begin{tabular}{|c|c|c|c|}
\hline Avg. calls per day & Number of subjects & $\%$ of subjects & Total calls \\
\hline 0 & 2 & 1.005 & 0 \\
\hline 1 & 26 & 13.065 & 26 \\
\hline 2 & 39 & 19.598 & 78 \\
\hline 3 & 31 & 15.578 & 93 \\
\hline 4 & 14 & 7.035 & 56 \\
\hline 5 & 40 & 20.101 & 200 \\
\hline 6 & 10 & 5.025 & 60 \\
\hline 7 & 2 & 1.005 & 14 \\
\hline 8 & 4 & 2.01 & 32 \\
\hline 10 & 23 & 11.558 & 230 \\
\hline 13 & 1 & 0.503 & 13 \\
\hline 15 & 1 & 0.503 & 15 \\
\hline 20 & 3 & 1.508 & 60 \\
\hline 25 & 1 & 0.503 & 25 \\
\hline 30 & 1 & 0.503 & 30 \\
\hline 50 & 1 & 0.503 & 50 \\
\hline
\end{tabular}

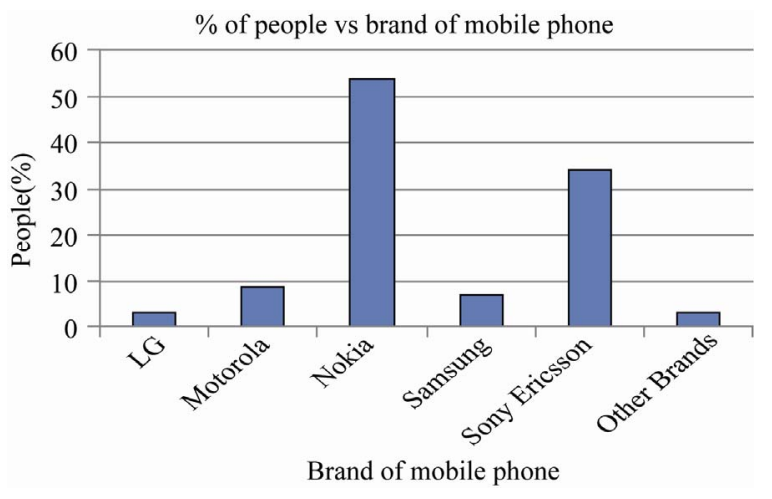

Figure 5. Distribution of brand of mobile phone according to number of subjects.

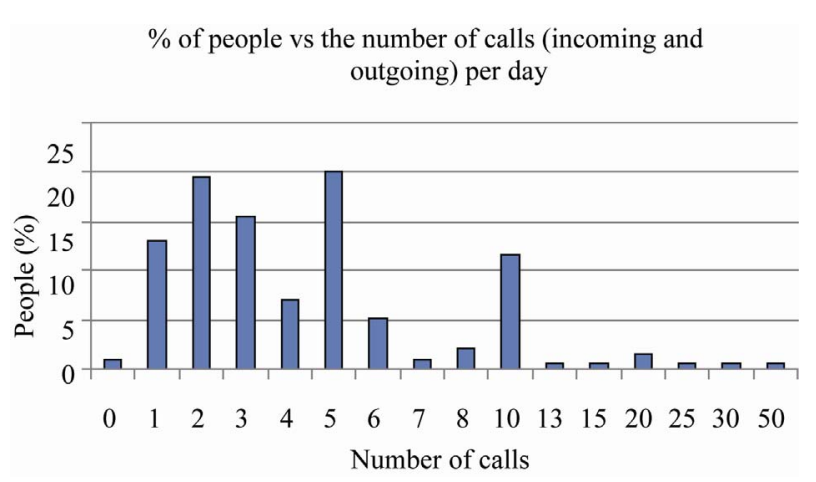

Figure 6. The usage of mobile phone is more among females as compared to males.

Openly accessible at http://www.scirp.org/journal/HEALTH/ 


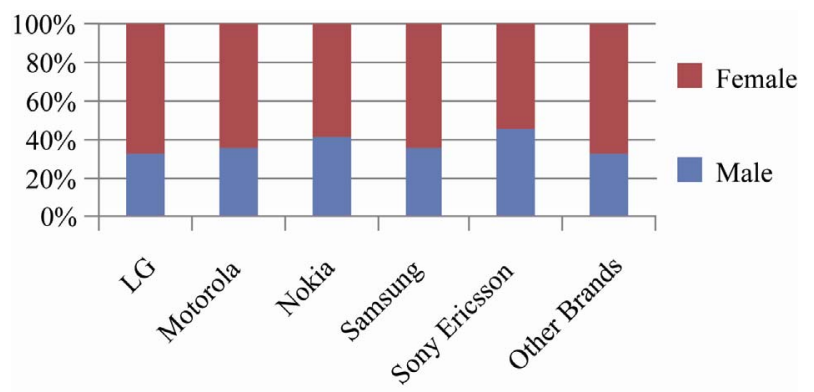

Figure 7.

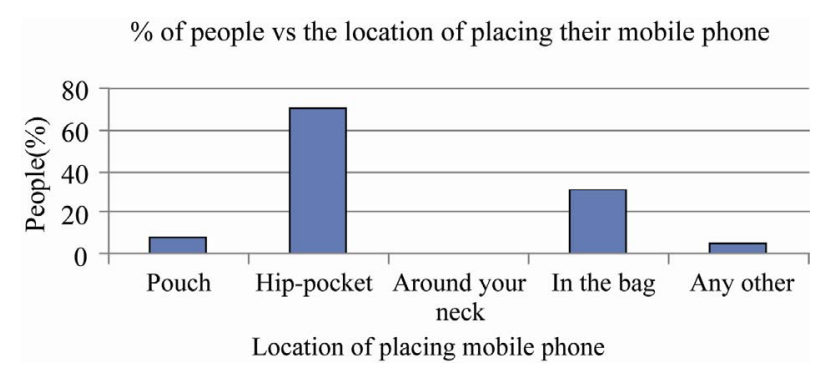

Figure 8.

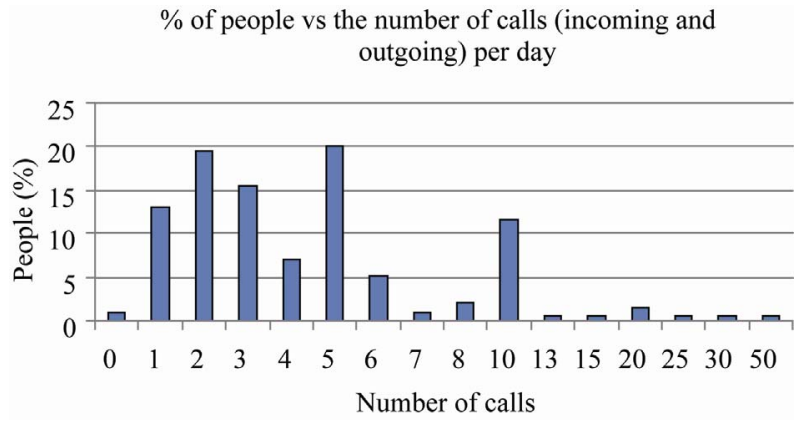

Figure 9. Duration per call (in minutes) according to number of subjects.

$\%$ of people vs average duration of calls (incoming and outgoing) per day

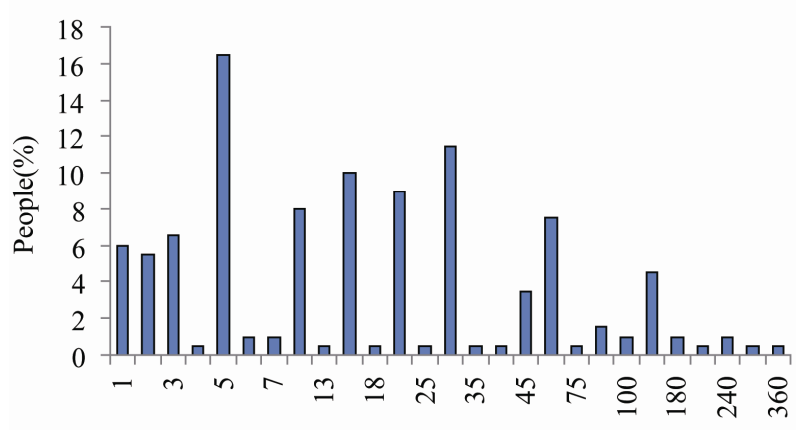

Average duration of calls

Figure 10. Ear used in the subjects : Majority, $48 \%$ of the subjects used their right ear and $18.5 \%$ used left ear.

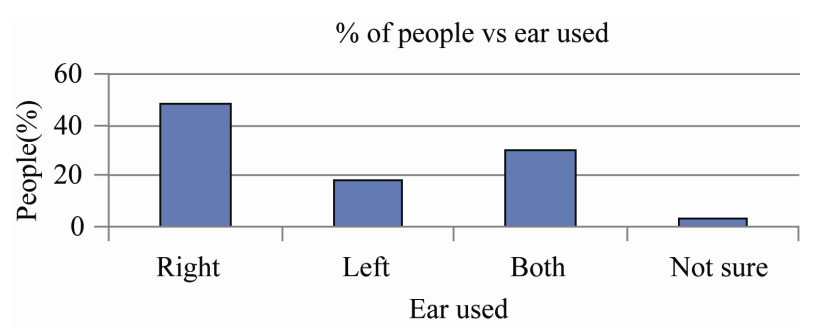

Figure 11. Right ear is preferred more than left ear for speaking on mobile phone. Both females and males prefer using right ear than left ear.

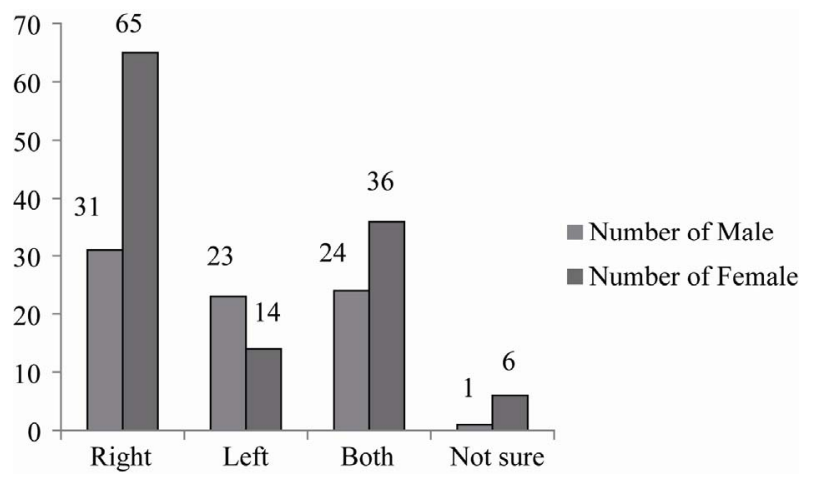

Figure 12. Distribution of the overall mobile phone hazard perception by gender.

hazard while driving was found to be $39.5 \%$.A study had conducted in Japan by Ichikawa and Nakahara [18] on high school student on usage of mobile phone while cycling has revealed higher bicycle crash. The risks of mobile phone usage on visual attention, peripheral vision, bronchial asthma, road accidents and living near base stations have been reported [19-22]. A descriptive analytical study on mobile phone risks in University students in Malaysia has been undertaken here (Table 3, Figure 17).

A. Reasons for not responding to the questionnaire

I. During the survey, some of the student refused to become the subject of our study. It is basically due to the reasons below:

Laziness, felt irrelevant to their academic studies, didn't think they will make a difference in the study, inade- quate ideas of details like number of SMS and duration of calls

\section{B. Semi-structured interview:}

I.A. The brand used most by AIMST University students is Nokia and it is followed by Sony Ericsson, Samsung and Motorola. Semi-structured interviews were conducted to get an idea for the rationale of choosing a particular brand of mobile phone, not preferring hand free and the reasons for not practicing reduced mobile phone usage. 


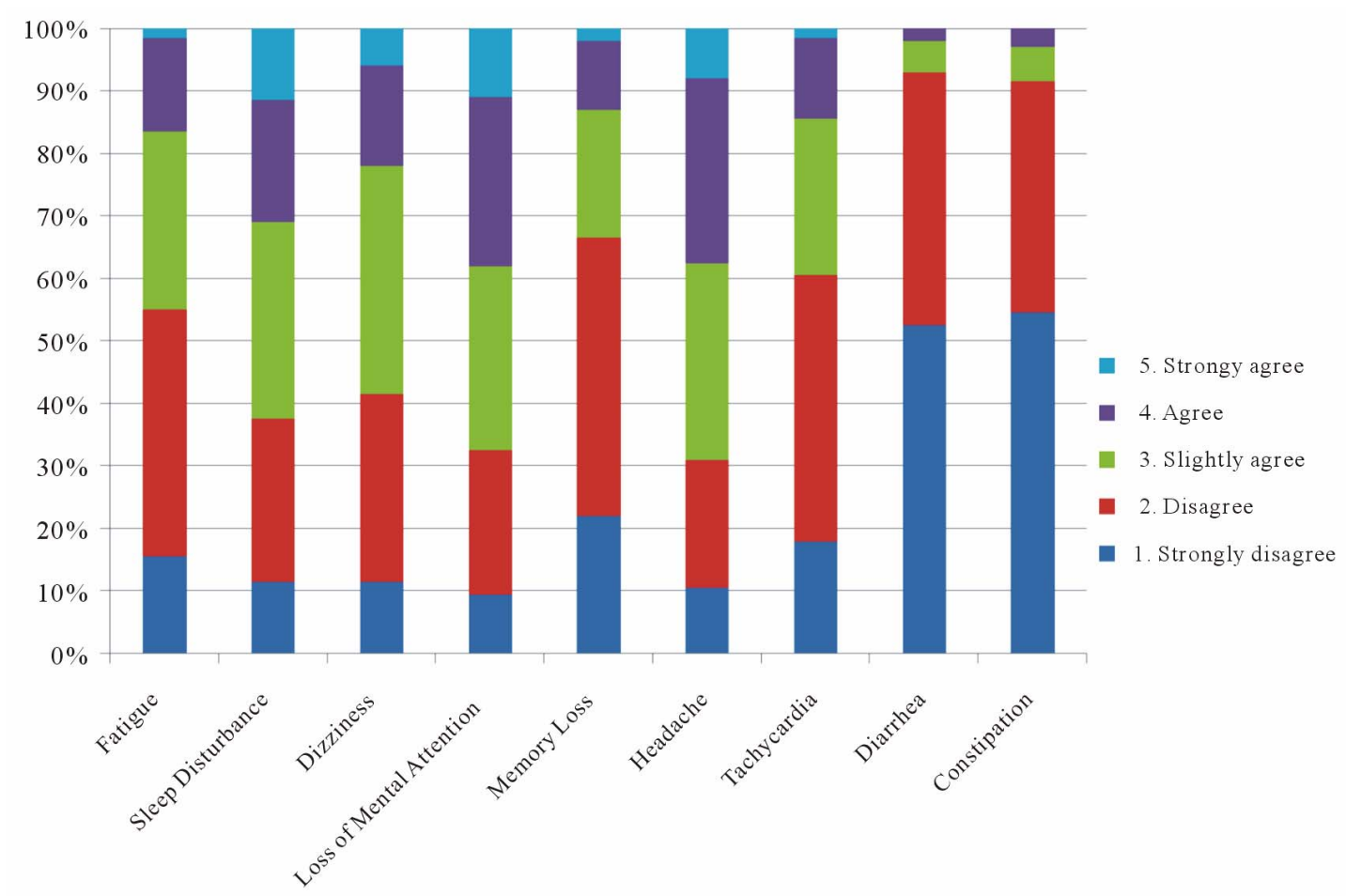

Figure 13. Distribution of percentage of perception of side effects of mobile phone given by participants sorted by male and female .

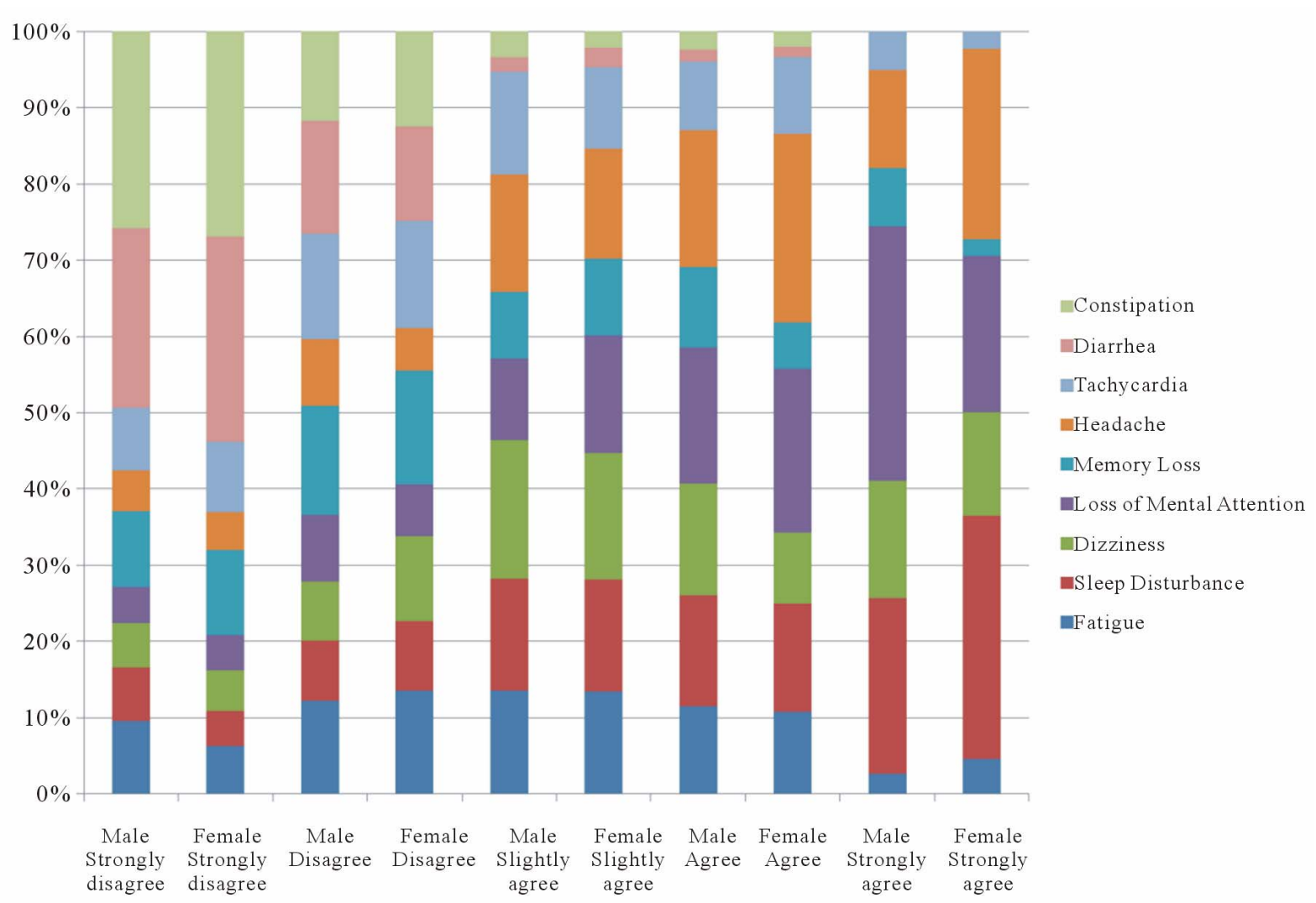

Figure 14. Association of factors of mobile phone hazard perception in males $(\mathrm{N}=79)$. 


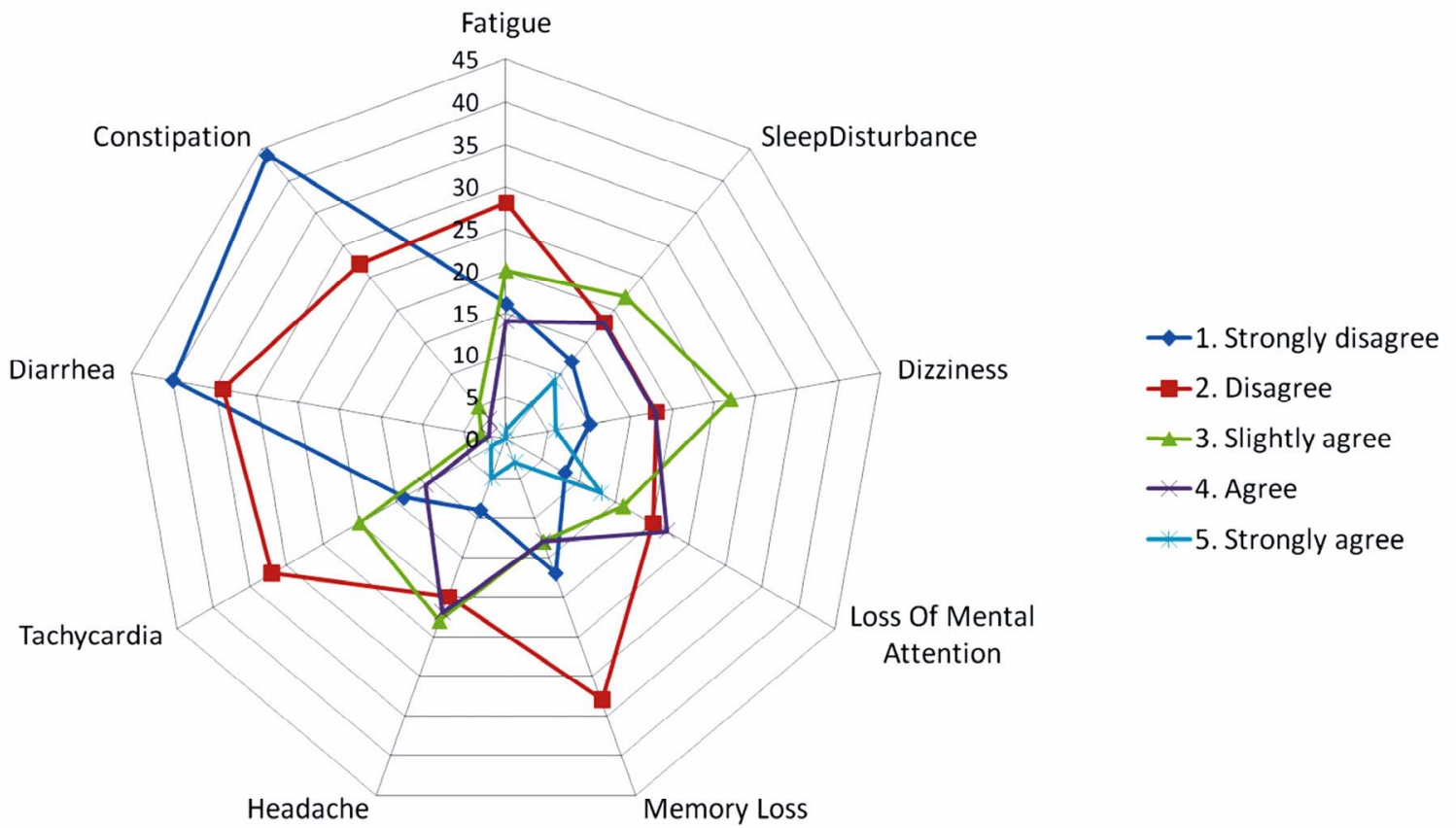

Figure 15. Association of factors of mobile phone hazard perception in females $(\mathrm{N}=121)$.

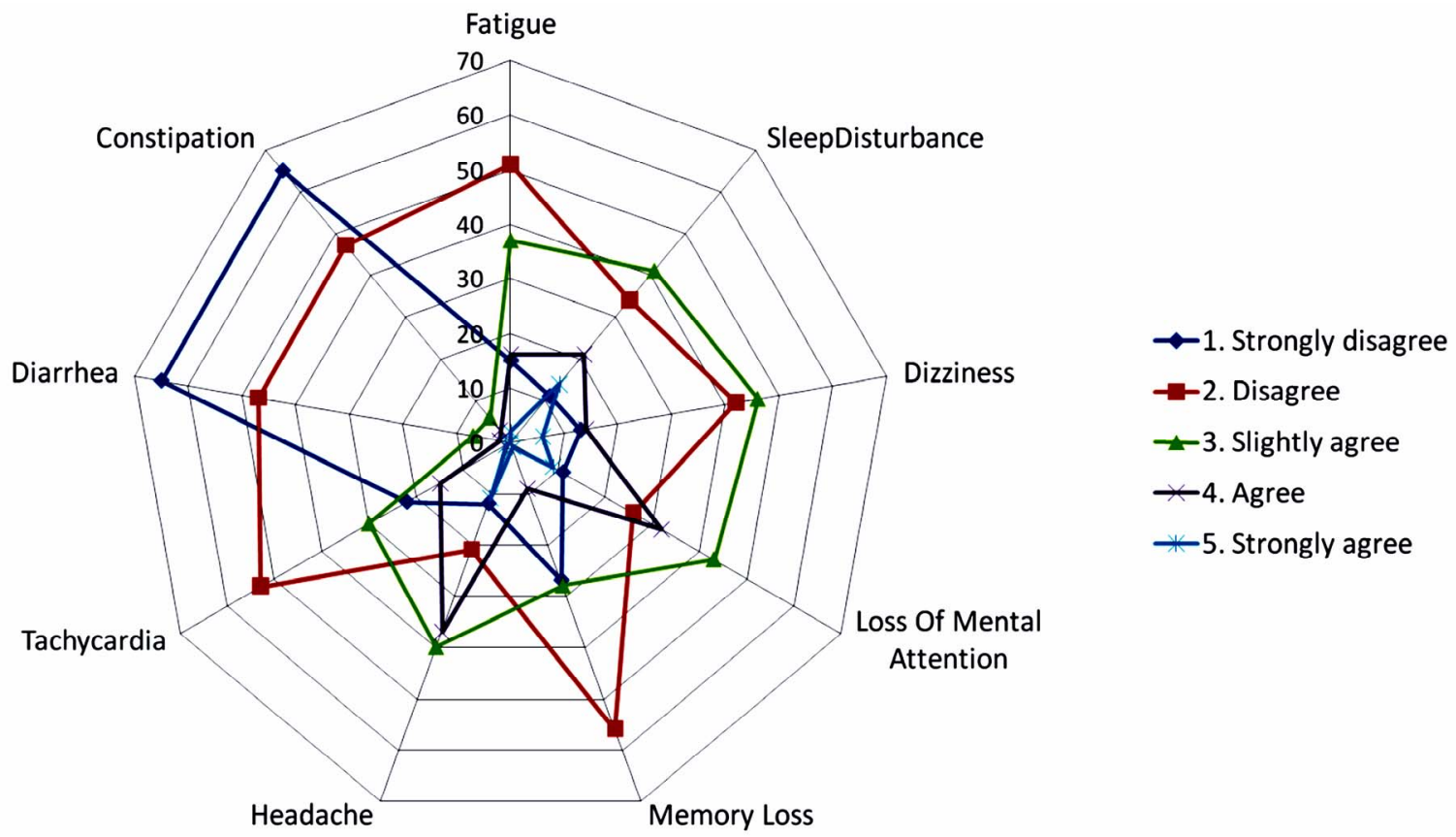

Figure 16. Awareness of hazards depicted in percentage.

Table 3. Need to minimize mobile phone usage and percentage of males and females.

\begin{tabular}{ccccc}
\hline & Male & Male \% & Female & Female \% \\
\hline No need minimize & 3 & $5 \%$ & 10 & $10 \%$ \\
Decrease talking duration & 36 & $60 \%$ & 57 & $51 \%$ \\
Increase hands free length & 21 & $35 \%$ & 44 & $39 \%$ \\
\hline
\end{tabular}




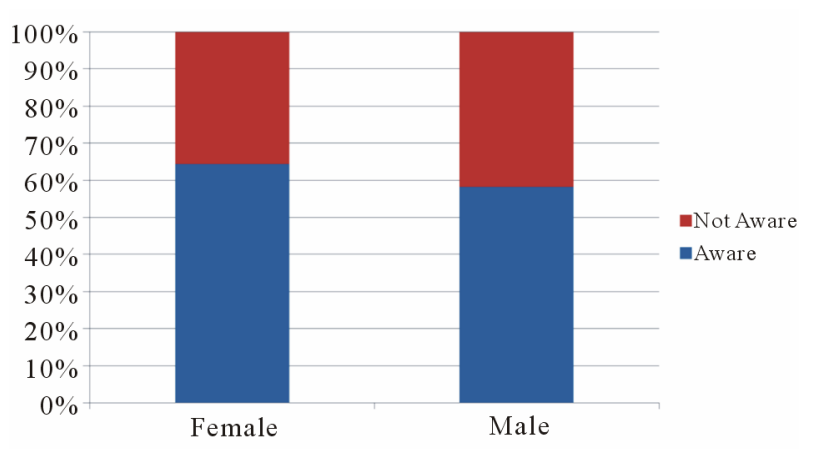

Figure 17. Radar graph shows the percentage of population who did not feel there is a need to minimize and the preferred way to minimize the hazard (amongst those who felt the need to minimize).

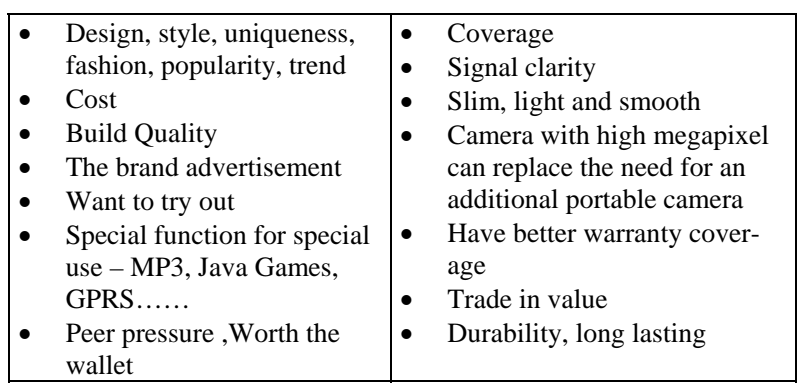

I.B. Gender preference:

Female prefer - Colorful, slim, lightweight, lasting, stylish mobile phone

Male prefer - Stylish, trendy, good performance mobile phone

II. Hands free are normally not preferred because of the need to plug in and out when needed and this may spoil the delicate port, not feel good to plug earpiece in your ear while walking around, not comfortable to use noisy, not good reception, dangling wires and controls interfere, not too stylish and people may feel that they are talking to themselves rather than talking to the phone during calls.

III. Most of the student population gave a feedback that their perception has increased after completing the "perception questionnaire". In spite of the increased awareness of risk, they chose not to practice reduction in mobile phone usage due to the following reasons: How is possible to reduce a call if receiving call from someone important, Don't have the idea of "Keep It Short and Simple" and now mobile company offer - "the more you talk, the cheaper it charges" and hence why not grab the opportunity.

\section{Qualitative analysis:}

These are some of the opinion given on "What are the unwanted effects.”
1 Headache destroys brain cells.

2 Hearing problems, radiation, Ca, tumor.

3 Mutation of genes.

4 Slight heat.

5 Infertility.

6 Pimples.

7 Earache.

8 Reactive waves.

9 Vasodilatation of blood vessels near the ear.

10 Mental retardation.

11 Nausea.

12 Impotence in man.

13 Prostate Carcinoma.

These are some of the opinion given on "By which other method can you minimize the unwanted effect."

1 Reduce by using infrared.

2 Put hand phone away from body.

3 Use loud speaker mode.

4 Switch phone off when not in use.

5 Put phone away in locker.

6 Use earphones.

7 Use public phones.

8 Don't use frequently.

These are some of the opinion given on "why are you not practicing the method even though you are aware of the hazard."

1 No hands free.

2 Laziness.

3 Not realized.

4 Difficult to practice.

5 Troublesome.

6 Never bothered about it.

7 Have never experience any side effect.

There is a significant number of people take laziness as their excuse to not practice any of the method minimizing the hazard, despite they had know the side effects. However, some are not bothered as the importance of the hand phone usage as part of the daily life outweighs the measures to counter the side effect.

Limitations: We did not have a control population as all our students possessed mobile phone.

\section{CONCLUSIONS}

The perception of mobile phone hazards among AIMST University students was found to be $62 \%$. Our hypothesis was proved wrong and we discovered a higher percentage of perception of mobile phone hazards among AIMST University students. Mobile phone has added new dimensions after its invention. Among the favorable outcomes is the use of mobile phone for seeking help, reporting crime, reckless driving or emergency. The increased perceived safety associated with it may outweigh the unfavorable risk associated with mobile 
phone.

Future direction: Advantages and disadvantages of mobile phones, Risk of using mobile while driving, Specific absorption rate and electric field measurements of mobile phones and Perception of usefulness of mobile phone shield are being considered for further studies.

\section{REFERENCES}

[1] Coggon, D. (2005) What are the health risks associated with mobile phones and their base stations? http://www.who.int/features/qa/30/en/

[2] Kraut, R., Patterson, M., Lundmark, V., Kiesler, S., Mukopadhyay, T. and Scherlis, W. (1998) Internet-paradox: A social technology that reduces social involvement and psychological well being? American Psychologist, 53, 1017-1031. doi:10.1037/0003-066X.53.9.1017

[3] Maier, M. (2000) The health hazards of mobile phones. British Medical Journal, 320, 1288-1289. doi:10.1136/bmj.320.7245.1288

[4] Hermann, D.A. and Hossmann, K.A. (1997) Neurological effects of microwave exposure related to mobile communication. Journal of the Neurological Sciences, 152, 1-14. doi:10.1016/S0022-510X(97)00140-8

[5] Braune, S., Wrocklage, C., Raczek, J., Gailus, T. and Lucking, C.H. (1988) Resting blood pressure increase during exposure to a radio-frequency electromagnetic field. The Lancet, 351, 1857-1858.

[6] Koivisto, M., Revonsuo, A., Krause, C., Haarala, C., Sillanmaki, L., Laine, M. and Hamalainen, H. (2000) Effects of $902 \mathrm{MHz}$ electromagnetic field emitted by cellular telephones on response times in humans. Neuroreport, 11, 413-415. doi:10.1097/00001756-200002070-00038

[7] Freude, G., Ullsperger, P., Eggert, S. and Ruppe, I. (1988) Effects of microwaves emitted by cellular phones on human slow brain potentials. Bioelectromagnetics, 19, 384-387. doi:10.1002/(SICI)1521-186X(1998)19:6<384::AID-BE M6>3.0.CO;2-Y

[8] Krause, C.M., Sillanmaki, L., Koivisto, M., Haggqvist, A., Saarela, C. and Revonsuo, A. (2000) Effects of electromagnetic field emitted by cellular phones on the EEG during a memory task. Neuroreport, 11, 761-764. doi:10.1097/00001756-200003200-00021

[9] Hermann, D.A. and Hossmann, K.A. (2003) Effects of electromagnetic radiation of mobile phones on the central nervous system. Bioelectromagnetics, 24, 49-62. $\underline{\text { doi:10.1002/bem. } 10068}$
[10] Siegrist, M., Earle, T.C., Gutscher, H. and Keller, C., (2006) Perception of mobile phone and base station risks. Risk Analysis, 26, 1021-1029. doi:10.1111/j.1539-6924.2006.00797.x

[11] Chapman, S. and Schofield, W.N. (1998) Emergency use of cellular (mobile) telephones. The Lancet, 351, 650. doi:10.1016/S0140-6736(05)78435-X

[12] Hutter, H.P., Moshammer, H., Wallner, P. and Kundi, M. (2006) Subjective symptoms, sleeping problems, and cognitive performance in subjects living near mobile phone base stations, Occupational and Environmental Medicine, 63, 307-313. doi:10.1136/oem.2005.020784

[13] Hutter, H.P., Moshammer, H., Wallner, P. and Kundi, M. (2004) Public perception of risk concerning celltowers and mobile phones. Soz Praventivmed, 49, 62-66. doi:10.1007/s00038-003-2094-7

[14] Mallardi, V. (2005) The origin of informed consent. Acta Otorhinolaryngol Ital, 25, 312-327.

[15] Appelbaum, P.S., Lidz, C.W. and Klitzman, R. (2009) Voluntariness of consent to research: A conceptual model. The Hastings Center Report, 39, 30-39. doi:10.1353/hcr.0.0103

[16] Baum, N. (2006) Informed consent--more than a form. Journal of Medical Practice Management, 22, 145-148.

[17] Martha, C. and Griffet, J. (2007) Brief report: How do adolescents perceive the risks related to cell-phone use? Journal of Adolescence, 3, 513-521. doi:10.1016/j.adolescence.2006.11.008

[18] Ichikawa, M. and Nakahara, S. (2008) Japanese high school students' usage of mobile phones while cycling Traffic Injury Prevention, 9, 42-47. doi:10.1080/15389580701718389

[19] Krewski, D., Lemyre, L., Michelle, C., et al. (2009) Public perception of population health risks in "Canada: Health hazards and health outcomes". International Journal of Risk Assessment and Management, 11, 315334. doi:10.1504/IJRAM.2009.023158

[20] Maples, W.C., DeRosier, W., Hoenes, R., Bendure, R. and Moore, S. (2008) The effects of cell phone use on peripheral vision. Optometry, 79, 36-42. doi:10.1016/j.optm.2007.04.102

[21] Vanlaar, W. and Yannis, G. (2006) Perception of road accident causes. Accident Analysis \& Prevention, 38, 155. doi:10.1016/j.aap.2005.08.007

[22] Bush, A., Karagiannis, G.E., Stamatopoulos, V.G. and Kotis, T. (2006) Public perception of realtime information services for environmental monitoring and management of asthma. Journal of Telemedicine and Telecare, 12, 11-13. doi:10.1258/135763306777978470 


\section{APPENDIX 1: PERCEPTION} QUESTIONNAIRE ON MOBILE PHONE HAZARD STUDIES

1 Name :

2 Student ID :

3 Gender : male / female

4 Age :

5 Date of birth :

6 Course :

7 Year joining AIMST (MM/YY) :

8 Do you use a cell phone : yes / no

9 How long have you been using a cell phone (MM/YY) :__

10 How many cell phones you use currently :

11 Cell phone(s) brand that you're using :

12 Where do you carry your cell phone:

pouch / pocket / around your neck / in the bag / any other

13 Average no. Of calls received/dialed daily :

14 The average duration you talk (both incoming and outgoing) on the phone daily (in minutes):

14 Which ear that you normally use when you're on the phone:

right / left / both / not sure

16 Average no. of SMS received/sent daily:

17 Do you using any cell phone accessory(s):

Bluetooth: yes / no

Hands free: yes / no

18 Do you use cell phone while driving : yes / no

19 Each call in minutes received/called for 3 consecutive days :

\begin{tabular}{ll}
\hline$(1)$ & $(6)$ \\
$(2)$ & $(7)$ \\
$(3)$ & $(8)$ \\
$(4)$ & $(9)$ \\
$(5)$ & $(10)$ \\
\hline
\end{tabular}

1) Do you think the following health hazard are associated to cell phone usage

\begin{tabular}{|c|c|c|c|c|c|}
\hline $\begin{array}{l}\text { Health } \\
\text { hazards }\end{array}$ & $\begin{array}{l}\text { Strongly } \\
\text { disagree }\end{array}$ & Disagree & $\begin{array}{l}\text { Slightly } \\
\text { agree }\end{array}$ & Agree & $\begin{array}{c}\text { Strongly } \\
\text { agree }\end{array}$ \\
\hline Fatigue & & & & & \\
\hline $\begin{array}{l}\text { sleep } \\
\text { disturbance }\end{array}$ & & & & & \\
\hline Dizziness & & & & & \\
\hline $\begin{array}{l}\text { loss of mental } \\
\text { attention }\end{array}$ & & & & & \\
\hline memory loss & & & & & \\
\hline Headache & & & & & \\
\hline $\begin{array}{l}\text { tachycardia } \\
\text { (increased } \\
\text { heart rate) }\end{array}$ & & & & & \\
\hline Diarrhea & & & & & \\
\hline constipation & & & & & \\
\hline
\end{tabular}

2) Are you aware of the several unwanted effects of using the cell phone : yes/no

3) How do you think you can minimize the unwanted effects :

a) Decrease the talking duration : yes/no

b) Increase the length of hands free: yes/no

c) Any other method(s):

4) Do you actually practice any of these measures: yes / no

5) If no, why? 